\title{
PENGARUH PELATIHAN TERHADAP KINERJA KARYAWAN DI FAVE HOTEL HYPERSQUARE BANDUNG
}

\author{
Arisman Muchtar ${ }^{1}$ \\ STIEPAR YAPARI, Bandung \\ arisman_muchtar@yahoo.com \\ Khoirul Fajri $^{2}$ \\ STIEPAR YAPARI, Bandung \\ khoirul.fajri@yahoo.com \\ Ulima Mahsa Aditia ${ }^{3}$ \\ Alumni STIEPAR YAPARI, Bandung. \\ mahsyau5@gmail.com
}

\begin{abstract}
ABSTRAK
Sumber daya manusia, merupakan faktor penggerak terpenting dari roda organisasi atau perusahaan. Perusahaan berupaya untuk meningkatkan kualitas karyawan dengan melaksanakan program pelatihan. Dalam pemberian pelatihan, diperlukan program pelatihan secara konsisten,terencana dan berkesinambungan. Sehingga setiap karyawan dapat mengembangkan kemampuannya dalam bekerja dan dapat memberikan kepuasan terhadap perusahaan atau tempat dimana mereka bekerja.

Karyawan di Fave hotel Hypersquare dalam melakukan tugas kerjanya masih sering melakukan kesalahan-kesalahan yang tidak sesuai dengan standar operasional kerjanya, hal ini kemungkinan terjadi karena karyawan tidak terlalu memahami bagaimana proses penyelesaian pekerjaan dengan baik dan benar.

Berdasarkan hasil penelitian dapat diketahui pengaruh pelatihan (X) terhadap kinerja karyawan (Y) di Favehotel Hypersquare dapat dinyatakan positif dan signifikan dimana $t$ hitung sebesar 7.973 lebih besar dari $t_{\text {tabel }}=1,98$. Dengan demikian dapat dinyatakan bahwa $\mathrm{H} 0$ ditolak $\mathrm{H} 1$ diterima dengan kata lain terdapat pengaruh signifikan antara variabel pelatihan $(\mathrm{X})$ sebagai variabel independen terhadap variabel kinerja karyawan (Y) sebagai variabel dependen.
\end{abstract}

Kata Kunci : Pelatihan, Kinerja karyawan 


\title{
THE INFLUENCE OF TRAINING ON THE PERFORMANCE OF EMPLOYEES IN FAVE HOTEL HYPERSQUARE BANDUNG
}

\begin{abstract}
The human resources department is the most important driving factors of the organization or company. The Company seeks to improve the quality of employees with the training program. In the provision of training, we need a consistent training program, planned. Therefore, each employee can develop his ability to work so as to give satisfaction to the company or the place where they work.

Employees of Fave hotel Hypersquare when they are working still made mistakes and it is not accoradance with standard operational procedure. This case possibility that employees are not understands how to process a job with good and true.

Based on the results of this research is the effect of training $(X)$ on employee performance $(Y)$ in Favehotels Hypersquare can be expressed positively and significantly where $t$ count for 7.973 is greater than t table $=1.98$. And it can be stated that $H O$ is rejected $H 1$ received in other words there is significant influence between the variables of training $(X)$ as the independent variable on the employee performance variable $(Y)$ as the dependent variable.
\end{abstract}

Keywords: Training, Employee Performance

\section{PENDAHULUAN}

Pariwisata telah menjadi salah satu kebutuhan yang tidak dapat dipisahkan dari kehidupanmanusia dan menjadi sumber devisa. Hal itu dapat dilihat dari terus berkembangnya pariwisata di berbagai negara di dunia. Salah satu faktor pendorong keberlangsungan pada bisnis pariwisata ini adalah industri perhotelan. Dewasa ini bisnis perhotelan tumbuh dan berkembang sangat pesat. Hal ini terbukti dengan semakin meningkatnya jumlah hotel. Dengan tumbuh berkembangnya hotel, maka tanpa disadari telah terjadi persaingan. Oleh karena itu, menuntut bisnis ini untuk mampu beradaptasi dengan perubahan dan perkembangan yang ada.

Di antara sekian banyak hotel yang ada, di Bandung terdapat Favehotel Hypersquare. Hotel ini berupaya untuk meningkatkan kualitas karyawan dengan melaksanakan program pelatihan. Dalam pemberian pelatihan diperlukan program pelatihan secara konsisten,terencana dan berkesinambungan. Disisi lain, setiap karyawan dituntut untuk dapat mengembangkan kemampuannya dalam bekerja sehingga dapat meningkatkan kinerjanya.

Berdasarkan observasi awal yang penulis lakukan pada bagian Personalia Favehotel Hypersquare, ternyata pihak manajemen masih menemukan kesalahan proses kerja dari karyawannya yang sering terjadi contohnya, pada saat seorang karyawan yang bertugas sebagai kasir akan menginput data melaui sistem atau 
bisa disebut juga sebagai software hotel. Favehotel Hypersquare itu sendiri menggunakan software hotel VHP (Visual Hotel Program), pada umumnya karyawan sering mengalami kesalahan dalam menginput data yang kemudian akan berpengaruh besar pada hasil laporan hotel yang harus dipertanggung jawabkan maka dari itu pelatihan VHP sangat penting dilakukan kepada seluruh karyawan.

Berdasarkan permasalahan diatas maka penulis tertarik menulisjurnal dengan judul "Pengaruh Pelatihan Terhadap Kinerja Karyawan Di Fave hotel Hypersquare Bandung." Adapun tujuan dan kegunaan penelitian ini adalah untuk mengetahui pelaksanaan pelatihan yang dilakukan fave hotel hypersquare,untuk mengetahui kinerja karyawan fave hotel hypersquare, dan untuk mengetahui besar pengaruh pelatihan terhadap kinerja karyawan Fave hotel Hypersquare.

\section{KAJIAN PUSTAKA}

Secara Etimologi pariwisata berasal dari dua kata yaitu "pari" yang berarti banyak/berkeliling, sedangkan pengertian wisata berarti "pergi". Didalam kamus besar indonesia pariwisata adalah suatu kegiatan yang berhubungan dengan perjalanan rekreasi. Sedangkan menurut Undang-Undang No.10 tahun 2009, "Pariwisata adalah berbagai macam kegiatan wisata dan didukung berbagai fasilitas serta layanan yang disediakan oleh masyarakat, pengusaha, pemerintah, dan Pemerintah Daerah."

Dalam melaksanakan kegiatan pariwisata tidak terlepas dari kesan-kesan indah yang merupakan akumulasi dari perjalanan dan pendukung pariwisata itu sendiri. Pendukung itu di antaranya adalah akomodasi atau hotel. Sebagaimana diungkap oleh Titing Kartika, "Industri pariwisata mencakup beberapa sektor, di antaranya adalah akomodasi, restaurant dan atraksi wisata. Akomodasi sebagai tempat menginap wisatawan selama perjalanan wisata yang lebih dari satu hari, antara lain hotel, motel, losmen, dan jenis penginapan lainnya." Karena itu, pariwisata dan hotel merupakan satu kesatuan yang tidak dapat dipisahkan. Namun demikian, baik buruknya pelayanan pariwisata dan hotel sebagai sarana pendukung sangat bergantung dari manajemen dari sumber daya manusia yang ada.

\section{Manajemen Sumber Daya Manusia}

Menurut Emron Edison, Yohny Anwar dan Imas Komariyah (2016:10), "Manajemen sumber daya manusia (MSDM) adalah manajemen yang memfokuskan diri pada kemampuan karyawan atau anggotanya melalui berbagai langkah strategis dalam rangka meningkatkan kinerja pegawai/karyawan menuju pengoptimalan tujuan organisasi." Sedangkan menurut Mathis dan Jackson (2006:3), "Manajemen Sumber daya manusia adalah rancangan system-sistem formal dalam sebuah organisasi untuk memastikan penggunaan bakat manusia secara efektif dan efisien guna mencapai tujuan organisasi." Hasibuan (2003:10) menjelaskan bahwa, "Manajemen sumber daya manusia adalah ilmu dan seni mengatur hubungan dan peranan tentang tenaga kerja agar efektif dan efisien membantu terwujudnya tujuan perusahaan karyawan dan masyarakat." 


\section{Fungsi Manajemen Sumber Daya manusia}

Menurut Hasibuan (2003:21), "fungsi manajemen sumber daya manusia terdiri dari perencanaan, pengorganisasian,pengarahan,pengendalian, pengadaan, pengembangan kompensasi, pengintegrasian, pemeliharaan, kedisiplinan dan pemerhentian."

a. Perencanaan

Perencanaan SDM (human resources planing) adalah perencanaan tenaga kerja secara efektif serta efisien agar sesuai dengan kebutuhan perusahaan dalam membantu terwujudnya tujuan.

b. Pengorganisasian

Pengorganisasian adalah kegiatan untuk mengorganisasi semua karyawan dengan menetapkan pembagian kerja, hubungan kerja, delegasi wewenang, integrasi, dan koordinasi dalam bagan organisasi.

c. Pengarahan

Pengarahan adalah kegiatan melakukan kegiatan mengarahkan semua karyawan, agar mau bekerja sama dan bekerja efektif serta efisien dalam membantu tercapainya tujuan perusahaan, karyawan, dan masyarakat.

d. Pengendalian

Pengendalian adalah kegiatan mengendalikan semua karyawan, agar mentaati peraturan-peraturan perusahaan dan bekerja sesuai dengan rencana.

e. Pengadaan

Pengadaan adalah proses penarikan, seleksi, penempatan, orientasi dan induksi untuk mendapatkan karyawan yang sesuai dengan kebutuhan perusahaan.

f. Pengembangan

Pengembangan (development) adalah proses peningkatan keterampilan teknis, teoritis, konseptual, dan moral karyawan melalui pendidikan dan pelatihan.

g. Kompensasi

Kompensasi adalah pemberian balas jasa langsung (direct) dan tidak langsung (indirect), uang atau barang kepada karyawan sebagai imbalan jasa yang di berikan kepada perusahaan.

h. Pengintegrasian

Pengintegrasian adalah kegiatan untuk mempersatukan kepintangan perusahaan dan kebutuhan karyawan, agar tercipta kerja sama yang serasi dan saling menguntungkan.

i. Pemeliharaan

Pemeliharaan (maintenance) adalah kegiatan untuk memelihara atau meningkatkan kondisi fisik, mental dan loyalitas karyawan agar mereka tetap mau bekerja sama sampai pension.

j. Kedisiplinan

Kedisiplinan merupakan fungsi MSDM yang terpenting dan kunci terwujudnya tujuan karena tanpa disiplin yang baik sulit terwujud tujuan yang maksimal. 
k. Pemberhentian

Pemberhentian (separation) adalah putusnya hubungan kerja seseorang dari suatu perusahaan. Pemberhentian ini disebaban keinginan karyawan, keinginan perusahaan, kontrak kerja berakhir, pensiun dan sebab-sebab lainnya.

\section{Pelatihan}

Tidak dapat disangkal bahwa manajemen sumber daya manusia itu sangat penting dalam meningkatkan kinerja karyawan. Tentunya untuk meningkatkan kinerja maka diperlukan pelatihan-pelatihan yang dilakukan secara terus menerus sehingga membentuk kompetensi yang diharapkan.

Menurut Mathis dan Jackson (2004: 301),"Pelatihan adalah sebuah proses dimana orang mendapatkan kapabilitas untuk membantu pencapaian tujuan organisasional. Dalam pengertian terbatas, pelatihan adalah memberikan karyawan pengetahuan dan keterampilan yang spesifik dan dapat diidentifikasi untuk digunakan dalam pekerjaan mereka saat ini." Sedangkan menurut Hadari Nawawi (2005:208), "Pelatihan adalah program-program untuk memperbaiki kemampuan melaksanakan pekerjaan secara individual, kelompok dan/atau berdasarkan jenjang jabatan dalam organisasi/perusahaan. Pelatihan juga merupakan proses melengkapi para pekerja dengan keterampilan khusus atau kegiatan membantu para pekerja dalam memperbaiki pelaksanaan pekerja yang tidak efisien."

\section{MANFAAT DAN TUJUAN PELATIHAN}

Menurut Hasibuan (2003;70) pengembangan karyawan bertujuan dan bersifat bagi perusahaan, karyawan, konsumen, atau masyarakat yang mengkonsumsi barang/jasa yang dilaksanakan perusahaan. Tujuan pengembangan hakikatnya menyangkut hal-hal berikut:

a. Produktivitas kerja

Dengan pengembangan, produktivitas kerja karyawan akan meningkat, kualitas dan kuantitas produksi semakin baik, karena technical skill, human skill, dan managerial skill karyawan yang semakin baik.

b. Efisiensi

Pengembangan karyawan bertujuan untuk meningkatkan efisiensi tenaga, waktu, bahan baku, dan mengurangi ausnya mesin-mesin. Pemborosan berkurang, biaya produksi relatif kecil sehingga daya saing perusahaan semakin besar.

c. Kerusakan

Pengembangan karyawan bertujuan untuk mengurangi kerusakan barang, produksi, mesin-mesin karena karyawan semakin ahli dan terampil dalam melaksanakan pekerjaannya.

d. Kecelakaan

Pengembangan bertujuan untuk mengurangi tingkat kecelakaan karyawan, sehingga jumlah biaya pengobatan yang dikeluarkan semakin ahli dan terampil dalam melaksanakan pekerjaannya. 
e. Pelayanan

Pengembangan bertujuan untuk meningkatkan pelayanan yang lebih baik dari karyawan kepada nasabah perusahaan, karena pemberian pelayanan yang baik merupakan daya penarik yang sangat penting bagi rekanan-rekanan perusahaan bersangkutan.

f. Moral

Dengan pengembangan, moral karyawan akan lebih baik karena keahlian dan keterampilannya sesuai dengan pekerjaannya sehingga antusias untuk menyelesaikan pekerjaannya dengan baik.

g. Karier

Dengan pengembangan, kesempata untuk meningkatkan karier karyawan semakin besar, karena keahlian, keterampilan, dan prestasi kerjanya lebih baik. Promosi ilmiah biasanya didasarkan kepada keahlian dan prestasi kerja seeorang.

h. Konseptual

Dengan pengembangan, manajer semakin cakap dan cepat dalam mengambil keputusan yang lebih baik, karena technical skill, human skill, dan managerial skill-nya lebih baik.

i. Kepemimpinan

Dengan pengembangan, kepemimpinan seseorang manajer akan lebih baik, human relation-nya lebih luwes, memotivasinya lebih terarah sehingga pembinaan kerja sama vertikal dan horizontal semakin harmonis.

j. Balas jasa

Dengan pengembangan, balas jasa (gaji, upah, insentif, dan benefits) karyawan akan meningkat karena prestasi kerja mereka semakin besar.

k. Konsumen

Pengembangan karyawan akan memberikan manfaat yang baik bagi masyarakat konsumen karena mereka akan memperoleh barang atau pelayanan yang lebih bermutu.

Menurut Anwar Prabu Mangkunegara (2001:45) tujuan pelatihan dan pengembangan yaitu:

1. Meningkatkan penghayatan jiwa dan ideologi.

2. Meningkatkan produktivitas kerja.

3. Menngkatkan kualitas kerja.

4. Meningkatkan ketetapan perencanaan sumber daya manusia.

5. Meningkatkan rangsangan agar pegawai mampu berprestasi secara maksimal.

6. Meningkatkan kesehatan dan keselamatan kerja.

7. Menghindarkan kesehatan dan keselamatan kerja.

8. Menghindari keusangan (obsolescence).

9. Meningkatkan perkembangan pegawai.

\section{Kinerja Karyawan}

Dengan adanya pelatihan, diharapkan kinerja karyawan meningkat. Di mana menurut Emron Edison, Yohny Anwar dan Imas 
Komariyah(2016:190), "Kinerja adalah hasil dari suatu proses yang mengacu dan diukur selama periode waktu tertentu berdasarkan ketentuan atau kesepakatan yang telah di tetapkan sebelumnya." Sedangkan pengertian manajemen kinerja menurut Michael Amstrong (2006:1) "Performance management can be defined as a systematic process for improving organizational performance by developing the performance of individual and teams"'(Manajemen kinerja dapat didefinisikan sebagai suatu proses yang sistematis untuk meningkatkan kinerja organisasi dengan mengembangkan kinerja individu dan tim).

Dengan demikian, dapat dimaknai bahwa kinerja yang optimal dan stabil, bukanlah sesuatu yang kebetulan. Tentunya sudah melalui tahapan dengan manajemen kinerja yang baik, dan usaha maksimal untuk mencapainya.Tanpa melalui manajemen kinerja yang baik, memungkinkan hasil yang dibanggakan sesungguhnya semu, sehingga, keberhasilan merupakan sebuah kebetulan yang bukan didasarkan pada fondasi yang kuat.

\section{Penilaian Kinerja Karyawan}

Yang dimaksud penilaian atau evaluasi kinerja menurut Wibisono (2006:

193) mengatakan,"Evaluasi kinerja merupakan penilaian kinerja yang dibandingkan dengan rencana atau standar-standar yang telah disepakati". Sedangkan menurut Simamora (2004:343) menyebutkan, "Evaluasi kinerja adalah untuk menghasilkan informasi yang akurat dan sahih tentang prilaku dan kinerja anggota organisasi. Semakin akurat dan sahih informasi yang dihasilkan oleh system penilaian kinerja, semakin besar potensi nilainya bagi organisasi."

\section{METODOLOGI PENELITIAN}

Desain yang digunakan di dalam penelitian ini adalah metode analisis deskriftif. Menurut Nazir (2005:54), pengertian metode deskriptif adalah sebagai berikut "Metode deskriptif adalah suatu metode dalam meneliti status sekelompok manusia, suatu objek, suatu set kondisi, suatu system pemikiran, ataupun suatu kelas peristiwa pada masa sekarang". Sedangkan menurut Zulganef (2008 :11), "Penelitian deskriptif adalah penelitian yang bertujuan menggambarkan suatu kondisi atau fenomena tertentu. Tidak memilah-milah atau mencari variable tertentu.

\section{Sumber Data}

Data yang digunakan dalam penelitian ini dikelompokan menjadi dua sumber yaitu:

1. Data Primer, yaitu data yang diperoleh langsung dari objek yang diteliti. Data ini berisikan informasi mengenai aktivitas yang sebenarnya terjadi dalam perusahaan. Data primer diperoleh dengan melakukan penelitian lapangan berupa wawancara serta kuesioner.

2. Data sekunder, yaitu data yang diperoleh secara tidak langsung dari objek yang diteliti. Data sekunder diperoleh dengan studi literature. 


\section{Penentuan Populasi dan unit sampel}

Penelitian ini membahas pengaruh pelatihan terhadap kinerja karyawan. Menurut Sugiyono (2010:115) mengatakan bahwa populasi adalah wilayah generalisasi, yang terdiri atas objek yang mempunyai kualitas dan karakteristik tertentu yang diterapkan oleh peneliti untuk dipelajari kemudian ditarik kesimpulannya. Populasi pada penelitian ini adalah karyawan favehotel hypersquare yang berjumlah 70 orang karyawan. Penelitian dilakukan dengan melalui sensus.

Sedangkan pengertian sampel itu sendiri menurut Sugiyono (2010:116) adalah bagian dari jumlah dan karakteristik yang dimiliki oleh suatu populasi tersebut. Menurut Umar (2008 : 107), "Sampel merupakan bagian terkecil dari suatu populasi."

\section{Teknik Pengumpulan Data}

Adapun teknik pengumpulan data yang digunakan oleh peneliti adalah sebagai berikut :

1. Observasi

Yaitu melakukan pengamatan secara langsung ke Favehotel Hypersquare Bandung untuk melihat dari dekat kegiatan yang dilakukan

2. Wawancara

Yaitu mengajukan pertanyaan kepada Human Resources Department Manager di Favehotel Hypersquare. Untuk megidentifikasi permasalahan yang ada serta mengetahui hal-hal dari responden yang lebih mendalam.

3. Kuesioner

Peneliti menyebar seperangkat pertanyaan tertulis kepada responden sebanyak 70 orang untuk dijawabnya. Dalam pengisian angket responden tinggal memilih alternative jawaban dengan cara melingkari atau memberi tanda silang dari salah satu jawaban yang dianggap paling tepat.

4. Studi dokumentasi

Dokumentasi diajukan untuk memperoleh data langsung dari tempat penelitian, meliputi buku-buku yang relevan, laporan kegiatan, fotofoto, dan data lainnya yang berhubungan dengan masalah yang dibahas.

\section{Operasional variable}

Definisi operasional adalah definisi yang didasarkan atas sifat-sifat hal yang didefinisikan yang dapat diamati atau diobservasi (utama, 2012:45) definisi operasional adalah penjelasan dari masing-masing variabel sehingga terbentuk beberapa indikator dari variabel tersebut yang akan dijabarkan pada instrumen penelitian.

Sugiyono (2009:33) mengatakan bahwa yang dimaksud dengan variabel bebas dan variabel terikat adalah "variabel bebas (independent variabel) 
merupakan variabel yang mempengaruhi atau menjadi sebab perubahan atau timbulnya variabel dependen (terikat). Variabel terikat (dependent variabel) merupakan variabel yang dipengaruhi atau menjadi akibat karena adanya variabel bebas".sedangkan definisi operasional variabel menurut Hermawan (2006:118) adalah bagaimana cara kita mengukur suatu variabel.

Untuk lebih jelasnya variabel-variabel dan indikator serta skala pengukuran dapat dilihat secara lebih rinci pada Tabel di bawah ini :

Tabel 2

Operasional Variabel

\begin{tabular}{|c|c|c|c|}
\hline Variabel & Dimensi & Indikator & Ukuran \\
\hline \multirow{5}{*}{$\begin{array}{l}\text { Pelatihan }(\mathbf{X}) \\
\text { Pelatihan adalah } \\
\text { memberikan karyawan } \\
\text { pengetahuan dan } \\
\text { keterampilan yang } \\
\text { spesifik dan dapat } \\
\text { diidentifikasi untuk } \\
\text { digunakan dalam } \\
\text { pekerjaan mereka saat } \\
\text { ini. }\end{array}$} & $\begin{array}{l}\text { Tujuan dan } \\
\text { Sasaran }\end{array}$ & $\begin{array}{l}\text { Pemahaman dan } \\
\text { kejelasan mengenai } \\
\text { tujuan dan sasaran. }\end{array}$ & $\begin{array}{l}\text { 1. Tingkat pemahaman } \\
\text { dan kejelasan dari } \\
\text { peserta tentang sasaran } \\
\text { dan tujuan pelatihan }\end{array}$ \\
\hline & Pelatih & $\begin{array}{l}\text { Memiliki keahlian, } \\
\text { kualifikasi, dan } \\
\text { professional }\end{array}$ & $\begin{array}{l}\text { 2. Tingkat keahlian pelatih } \\
\text { 3. Tingkat kualifikasi } \\
\text { pelatih } \\
\text { 4. Tingkat professional } \\
\text { pelatih dalam melatih }\end{array}$ \\
\hline & Materi & $\begin{array}{l}\text { Memiliki isi materi } \\
\text { yang sesuai dengan } \\
\text { tujuan yang hendak } \\
\text { dicapai }\end{array}$ & $\begin{array}{l}\text { 5. Tingkat kesesuaian isi } \\
\text { materi yang hendak } \\
\text { dicapai }\end{array}$ \\
\hline & Metode & $\begin{array}{l}\text { Penyesuaian } \\
\text { metode dengan } \\
\text { karyawan }\end{array}$ & $\begin{array}{l}\text { 6. Kesepahaman metode } \\
\text { yang akan diterapkan } \\
\text { dengan karyawan }\end{array}$ \\
\hline & $\begin{array}{l}\text { Peserta } \\
\text { pelatihan }\end{array}$ & $\begin{array}{l}\text { Pemenuhan syarat } \\
\text { dan ketentuan } \\
\text { peserta }\end{array}$ & $\begin{array}{l}\text { 7. Peserta yang dilatih } \\
\text { sesuai dengan bidang } \\
\text { pekerjaannya }\end{array}$ \\
\hline
\end{tabular}

\begin{tabular}{|c|c|c|c|}
\hline Variabel & Dimensi & Indikator & Ukuran \\
\hline $\begin{array}{l}\text { Kinerja (Y) } \\
\text { Kinerja adalah hasil } \\
\text { dari suatu proses yang } \\
\text { mengacu dan diukur } \\
\text { selama periode waktu } \\
\text { tertentu berdasarkan } \\
\text { ketentuan atau } \\
\text { kesepakatan yang telah }\end{array}$ & Target & $\begin{array}{l}\text { Fokus pada target } \\
\text { Menantang dan } \\
\text { realistis } \\
\text { Memenuhi } \\
\text { kuantitas } \\
\text { Pelanggan (Internal } \\
\text { dan eksternal) puas }\end{array}$ & 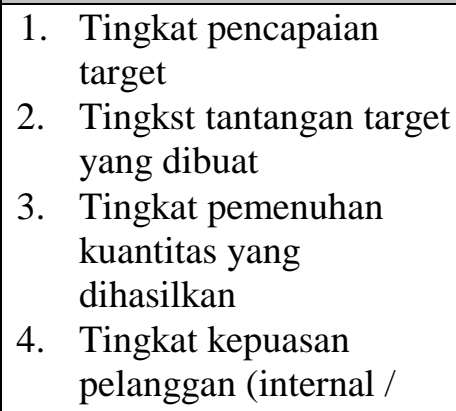 \\
\hline
\end{tabular}


Volume 2 Nomor 2 Juni 2017

\begin{tabular}{|c|c|c|c|}
\hline \multirow[t]{4}{*}{ ditetapkan sebelumnya } & & $\begin{array}{l}\text { atas kuantitas yang } \\
\text { dihasilkan }\end{array}$ & eksternal) \\
\hline & Kualitas & $\begin{array}{l}\text { Kualitas sesuai } \\
\text { dengan standar } \\
\text { yang sudah } \\
\text { ditetapkan } \\
\text { Anggota memiliki } \\
\text { komitmen tentang } \\
\text { kualitas } \\
\text { Memiliki prosedur } \\
\text { tentang pencapaian } \\
\text { kualitas } \\
\text { Pelanggan (internal } \\
\text { dan eksternal) puas } \\
\text { atas kualitas yang } \\
\text { dihasilkan } \\
\end{array}$ & 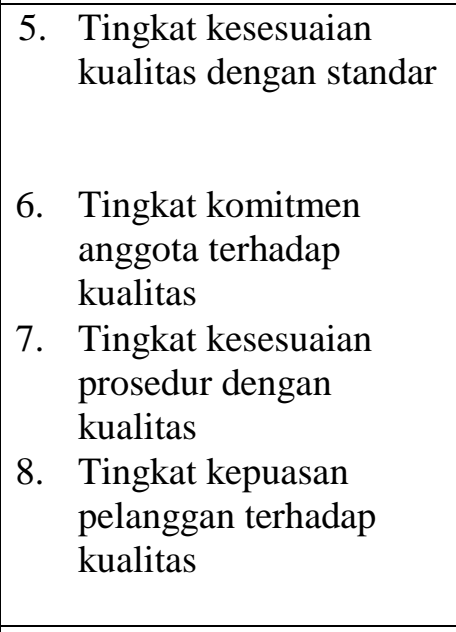 \\
\hline & Waktu & $\begin{array}{l}\text { Pekerjaan selesai } \\
\text { tepat waktu } \\
\text { Pelanggan puas } \\
\text { atas waktu } \\
\text { penyelesaian } \\
\text { Anggota } \\
\text { berkomitmen } \\
\text { terhadap } \\
\text { pentingnya } \\
\text { ketepatan waktu } \\
\end{array}$ & $\begin{array}{l}\text { 9. } \text { Tingkat penyelesaian } \\
\text { pekerjaan } \\
\text { 10. Tingkat kepuasan } \\
\text { pelanggan atas waktu } \\
\text { penyelesaian pekerjaan } \\
\text { 11. Tingkat komitmen } \\
\text { anggota terhadap } \\
\text { ketepatan waktu }\end{array}$ \\
\hline & Taat asas & $\begin{array}{l}\text { Dilakukan dengan } \\
\text { cara yang benar } \\
\text { Transferan dan } \\
\text { dapat } \\
\text { dipertanggung } \\
\text { jawabkan }\end{array}$ & $\begin{array}{l}\text { 12. Tingkat kebenaran } \\
\text { dalam proses } \\
\text { penyelesaian } \\
\text { 13. Tingkat transfaransi dan } \\
\text { pertanggung jawabanya }\end{array}$ \\
\hline
\end{tabular}

\section{UJI INSTRUMEN}

\section{Uji Validitas}

Menurut Ibnu Hadjar (1996), kualitas instrument penelitian ditentukan oleh dua kriteria utama: validitas dan reabilitas. Validitas suatu instrumen menurutnya menunjukan seberapa jauh ia dapat mengukur apa yang hendak diukur. Sedangkan reabilitas menunjukan tingkat konsistensi dan akurasi hasil pengukuran.

Menurut Sugiyono (2012:.267) "Validitas merupakan derajat ketepatan antara data yang terjadi pada objek penelitian dengan data yang dapat dilaporkan oleh peneliti”.

Uji validitas akan dihitung dengan menggunakan teknik korelasi product moment dengan menggunakan rumus sebagai berikut: 
Keterangan:

$$
r=\frac{n \sum x y-\left(\sum x\right)\left(\sum y\right)}{\sqrt{\left[n \sum x^{2}-(x)^{2}\right]\left[n \sum y^{2}-\left(\sum y\right)^{2}\right]}}
$$

$$
\begin{array}{ll}
r & =\text { koefisien validitas item yang dicari } \\
X & =\text { Skor yang diperoleh subjek dari seluruh item } \\
Y & =\text { Skor total } \\
\sum x & =\text { Jumlah skor dalam distribusi X } \\
\sum y & =\text { Jumlah skor dalam distribusi Y } \\
\left(\sum x^{2}\right) & =\text { Jumlah kuadrat dalam skor distribusi X } \\
\left(\sum y^{2}\right) & =\text { Jumlah kuadrat dalam skor distribusi Y } \\
n & =\text { Banyaknya responden }
\end{array}
$$

\section{Uji Reabilitas}

Menurut Sugiyono (2012:267), Reabilitas berkenaan dengan konsitensi dan stabilitas data atau temuan. Dalam pandangan positivistic ( kuantitatif ), suatu data dinyatakan reliable apabila dua atau lebih peneliti dalam objek yang sama menghasilkan data yang sama, atau peneliti yang ama dalam waktu yang berbeda menghasilkan data yang sama, atau sekelompok data bila dipecah menjadi dua menunjukan data yang tidak berbeda.

Uji reabilitas dapat dilakukan secara bersama - sama terhadap seluruh butir pertanyaan. Jika nilai Alpha $>0,60$ maka reliabel . Dengan rumus sebagai berikut:

$$
r\left[\frac{k}{(k-1)}\right]\left[1-\frac{\sum \sigma_{b}^{2}}{\sigma_{t}^{2}}\right]
$$

\section{V.Wiratna Sujarweni, 2014, hlm. 83}

$\boldsymbol{r} \quad=$ koefisien reliability instrument

$\boldsymbol{k} \quad=$ banyaknya butir pertanyaan

$\sum \sigma b^{2}=$ total varians butir

$\sigma t^{2}=$ total varians.

\section{TEKNIK ANALISIS DATA}

\section{Analisis Korelasi}

Analisis korelasi digunakan untuk mencari hubungan antara dua variabel yang diteliti. Rumus yang paling sederhana yang dapat digunakan untuk menghitung koefisien korelasi adalah dengan Pearson's Product Moment Cofficient of Correlation, (Sugiyono, 2005:182) sebagai berikut:

$$
r=\frac{n\left(\sum X Y\right)-\left(\sum X\right)\left(\sum Y\right)}{\sqrt{\left\{n\left(\sum X^{2}\right)-\left(\sum X\right)^{2}\right\}\left\{n\left(\sum Y^{2}\right)\left(\sum X\right)^{2}\right\}}}
$$


Koefisien korelasi $(r)$ menunjukan derajat korelasi antara X dan Y. Nilai koefisien korelasi harus terdapat dalam batas-batas $-1<\mathrm{r}<+1$. Tandapositif menunjukan adanya korelasi positif / korelasi langsung antara kedua variable yang diteliti. Setiap kenaikan nilai $\mathrm{X}$ akan diikuti dengan penurunan nilai $\mathrm{Y}$, begitu juga sebaliknya.

a. Jika nilai $r=+1$ atau mendekati +1 , maka korelasi antara kedua variable sangat kuat dan positif.

b. Jika $\mathrm{r}=-1$ atau mendekati -1 , maka korelasi antara kedua variable sangat kuat dan negatif.

c. Jika nilai $r=0$ atau mendekati 0 , maka korelasi antara kedua variabek sangat kuat dan negative.

Adapun kriteria keeratan hubungan antara variabel mengacu pada pendapat yang dikemukakan oleh sevilla et.al.(1997: 280), yang menyatakan bahwa "high or low correlation, dependens generally on the nature of variables being studied. You may, how ever the following categorization which most specialists in statistics usually agree with".

Untuk dapat memberikan penafsiran terhadap koefisien korelasi yang ditentukan besar atau kecil, maka dapat dilihat pada table dibawah ini :

Tabel 3

Pedoman Koefisien Korelasi

\begin{tabular}{|c|c|}
\hline Interval Koefisien & Tingkat Hubungan \\
\hline $0,00-0,199$ & Sangat rendah \\
\hline $0,20-0,399$ & Rendah \\
\hline $0,40-0,599$ & Sedang \\
\hline $0,60-0,799$ & Kuat \\
\hline $0,80-1,000$ & Sangat Kuat \\
\hline
\end{tabular}

Sumber: Sugiyono (2011:231)

\section{Analisis Regresi Linier Sederhana}

Analisis regresi digunakan untuk memprediksikan seberapa jauh perubahan nilai variabel dependen, jika nilai variabel independen dimanipulasi (dirubah-rubah atau dinaik turunkan). (Sugiyono, 2011:260)

Dalam analisis regresi linier sederhana, terdapat dua variabel yang diramalkan (dependent variabel) yaitu pelatihan dan (independent variabel) yaitu kinerja karyawan. Maka persamaan umum regresi linier sederhana menurut Puspowarsito (2008:165) adalah:

$$
Y=a+B x
$$

Dimana :

$\mathrm{Y}=$ Kinerja

$\mathrm{X}=$ Pelatihan 
$a=$ harga $\mathrm{Y}$ ketika $\mathrm{X}=0$ (harga konstan)

$b=$ angka arah atau koefisien regresi yang menunjukan angka peningkatan ataupun penurunan variabel dependen yang didasarkan pada perubahan variabel independen. Bila (+) arah garis naik. Dan bila (-) maka arah garis turun.

\section{Koefisien Determinasi}

Koefisien determinasi yaitu kuadrat korelasi. Untuk menguji seberapa besar pengaruh dari variabel pelatihan $(\mathrm{X})$ terhadap variabel kinerja $(\mathrm{Y})$, maka digunakan koefisien determinasi sebagai berikut :

$$
\mathrm{KD}=r^{2} \times 100 \%(\text { Sudjana, 2000:246) }
$$

Keterangan :

$\mathrm{KD}=$ Koefisien Determinasi

$r^{2}=$ Koefisien Korelasi

\section{HIPOTESIS PENELITIAN}

Hipotesis merupakan jawaban sementara terhadap rumusan masalah, dimana rumusan masalah telah dinyatakan dalam bentuk kalimat pertanyaan. Dikatakan sementara, karena jawaban yang diberikan baru didasarkan pada teori yang relevan, belum didasarkan pada fakta-fakta empiris yang diperoleh melalui pengumpulan. Jadi hipotesis juga dapat dinyatakan sebagai jawaban teoritis terhadap rumusan masalah penelitian, belum jawaban yang empirik (Sugiyono 2014:64). Berdasarkan teori dan kerangka pemikiran penulis menyatakan bahwa terdapat pengaruh signifikan antara pelatihan terhadap kinerja karyawan.

Untuk menguji signifikansi koefisien korelasi antara variabel $\mathrm{X}$ dan $\mathrm{Y}$ dilakukan dengan cara membandingkan $t_{\text {hitung }}$ dengan $t_{\text {tabel }}$ yaitu dengan menggunakan rumus distribusi student $\left(t_{\text {student }}\right)$

$$
t=\frac{r \sqrt{n-2}}{\sqrt{1-r^{2}}}(\text { Sugiyono, 2006: 184) }
$$

Keterangan :

$\mathrm{t}=$ distribusi student

$\mathrm{r}=$ koefisien korelasi roduct moment

$\mathrm{n}=$ banyaknya data

Kriteria pengambilan keputusan hipotesis yang diajukan adalah:

Jika $t_{\text {hitung }}>t_{\text {tabel }}$.maka $H_{0}$ ditolak dan $H_{1}$ diterima

Jika $t_{\text {hitung }}<t_{\text {tabel }}$.maka $H_{0}$ diterima dan $H_{1}$ ditolak

Secaa statistic, hipotesis yang akan diuji dalam rangka pengambilan dapat ditulis sebagai berikut:

Ho $: \rho=0 \quad$ Artinya tidak terdapat pengaruh antara pelatihan $(\mathrm{X})$ terhadap kinerja (Y)

Ha $: \rho>0 \quad$ Artinya terdapat pengaruh yang positif antara pelatihan dengan kinerja 


\section{HASIL DAN PEMBAHASAN}

\section{A. Uji Kualitas Data}

Di dalam melakukan penelitian ini, penulis menggunakan instrumen berupa kuesioner terdiri dari variabel pelatihan dan kinerja karyawan di Favehotel Hypersquare

Dari anggota populasi yang ada peneliti menetapkan jumlah responden sebanyak 70 responden karyawan di Favehotel Hypersquare. Langkah selanjutnya sebelum dilakukan penganalisaan lebih lanjut, terlebih dahulu perlu dilakukan pengujian terhadap validitas (ketepatan), reliabilitas (kehandalan) terhadap data dari 70 responden tersebut.

\section{Uji Validitas}

Instrumen akan dinyatakan valid apabila item yang mempunyai korelasi positif dengan skor total serta korelasi yang tinggi, menunjukkan bahwa item tersebut mempunyai validitas yang tinggi pula. Persyaratan minimum agar dapat dianggap valid apabila $r=0,300$. Sehingga apabila korelasi antar item dengan skor total kurang dari 0,300 maka item dalam instrument tersebut dinyatakan tidak valid (Sugiono 2010: 46). Berikut ini adalah hasil uji validitas item pertanyaan untuk masing-masing variabel sebagai berikut:

\section{1) Hasil Uji Validitas Instrumen Variabel Pelatihan}

Tabel 4

\section{Hasil Uji Validitas Pelatihan (X)}

\begin{tabular}{|c|c|c|c|}
\hline Item & Skor & R Kritis & Kategori \\
\hline X.1. & 0.495 & 0,300 & Valid \\
\hline X.2. & 0.383 & 0,300 & Valid \\
\hline X.3. & 0.411 & 0,300 & Valid \\
\hline X.4. & 0.332 & 0,300 & Valid \\
\hline X.5. & 0.368 & 0,300 & Valid \\
\hline X.6. & 0.504 & 0,300 & Valid \\
\hline X.7. & 0.536 & 0,300 & Valid \\
\hline
\end{tabular}

Sumber : Data Primer diolah kembali,2016

Pernyataan dalam instrumen variabel Pelatihan atas terdiri dari 7 item. Hasil uji variabel tersebut memenuhi kriteria yang disyaratkan karena di atas > 0,300 . 
2) Hasil Uji Validitas Instrumen Variabel Kinerja Karyawan (Y)

Tabel 5

Hasil Uji Validitas Variabel Kinerja (Y)

\begin{tabular}{|c|c|c|c|}
\hline Item & Skor & R Kritis & Kategori \\
\hline Y.1. & 0.360 & 0,300 & Valid \\
\hline Y.2. & 0.352 & 0,300 & Valid \\
\hline Y.3. & 0.364 & 0,300 & Valid \\
\hline Y.4. & 0.314 & 0,300 & Valid \\
\hline Y.5. & 0.596 & 0,300 & Valid \\
\hline Y.6. & 0.660 & 0,300 & Valid \\
\hline Y.7. & 0.326 & 0,300 & Valid \\
\hline Y.8. & 0.333 & 0,300 & Valid \\
\hline Y.9. & 0.323 & 0,300 & Valid \\
\hline Y.10. & 0.440 & 0,300 & Valid \\
\hline Y.11. & 0.342 & 0,300 & Valid \\
\hline Y.12. & 0.337 & 0,300 & Valid \\
\hline Y.13. & 0.566 & 0,300 & Valid \\
\hline
\end{tabular}

Sumber: Data Primer diolah kembali, 2016

Pernyataan dalam instrumen variabel Kinerja di atas terdiri dari 13 item. Hasil uji variabel tersebut memenuhi kriteria yang disyaratkan yaitu $>0,300$. Dengan demikian dapat disimpulkan bahwa butir pernyataan 1 sampai 13 dapat dinyatakan valid.

Tabel 6

Rekapitulasi Item Pertanyaan Instrumen

\begin{tabular}{|l|c|c|c|c|c|c|}
\hline \multirow{2}{*}{ Kuesioner/Variabel } & \multicolumn{2}{|c|}{ Valid } & \multicolumn{2}{c|}{ Tidak Valid } & \multicolumn{2}{c|}{ Total } \\
\cline { 2 - 7 } & Jumlah & \% & Jumlah & \% & Jumlah & \% \\
\hline Pelatihan & 7 & 100 & - & - & 7 & 100 \\
\hline Kinerja & 13 & 100 & - & - & 13 & 100 \\
\hline \multicolumn{1}{|c|}{ Jumlah } & 20 & & & & 20 & \\
\hline
\end{tabular}

Sumber: Lampiran hasil uji validitas- reliabilitas

\section{3) Hasil Uji Reliabilitas.}

Berdasarkan hasil pengujian reliabilitas terhadap kelima variabel Penelitian diperoleh hasil sebagai berikut: 
Tabel 7

Hasil Uji Reliabilitas

\begin{tabular}{|l|l|c|c|c|}
\hline No. & \multicolumn{1}{|c|}{ Variabel } & Skor & R Kritis & Kategori \\
\hline 1. & Pelatihan $(\mathrm{X})$ & 0,723 & 0,700 & Reliabel \\
\hline 2. & Kinerja karyawan $(\mathrm{Y})$ & 0,741 & 0,700 & Reliabel \\
\hline
\end{tabular}

Sumber: Data Primer diolah kembali, 2016

Hasil uji reliabilitas di atas dapat dinyatakan bahwa semua variabel termasuk kategori reliabel, karena skornya $>0,70$. Dengan demikian instrumen penelitian yang digunakan masing-masing variabel pada penelitian ini dapat dinyatakan reliabel dan benar-benar sebagai alat ukur yang handal dan memiliki tingkat kestabilan yang tinggi, dalam arti alat ukur tersebut apabila dilakukan secara berulang, hasil dari pengujian instrumen tersebut akan menunjukkan hasil yang tetap.

\section{B. Hasil Penelitian Deskriptif}

Penyampaikan hasil penelitian yang menjawab masalah deskriptif terhadap dua variabel yang diteliti adalah dengan menampilkan hasil perhitungan dengan nilai frekuensi, persentase, dan rata-rata untuk masing-masing indikator yang mendukung variabel melalui dimensi-dimensi. Rincian variabel dalam dukungan masing-masing indikator adalah sebagai berikut: (1) Variabel Pelatihan terdiri dari 7 pernyataan; (2) Variabel Kinerja terdiri dari $\mathbf{1 3}$ pernyataan. Berikut ini adalah hasil penelitian untuk masing-masing variabel.

\section{Variabel Pelatihan $(\mathrm{X})$}

Hasil penelitian terhadap variabel Pelatihan (X), dilakukan melalui hasil perhitungan terhadap masing-masing pernyataan pendukung variable pelatihan secara keseluruhan pelatihan karyawan berada pada kategori baik (rata-rata 3,94), khususnya materi yang diberikan telah sesuai dengan kebutuhan pekerjaan. Namun demikian masih terdapat aspek yang lemah, yaitu pada pernyataan mengenai instruktur masih kurang memiliki sikap menyenangkan, "Pelatihan merupakan faktor kunci penentu bagi seseorang dalam menghasilkan kinerja yang sangat baik.Dalam situasi kolektif.

\section{Variabel Kinerja Karyawan (Y)}

Hasil penelitian terhadap variabel Kinerja karyawan (Y), dilakukan melalui hasil perhitungan terhadap masing-masing pernyataan pendukung variable secara keseluruhan kinerja karyawan pada kreteria baik (rata-rata 3,87), khususnya karyawan telah memahami kualitas mutlak harus dipenuhi. Namun demikian, masih terdapat aspek yang lemah, yaitu mengenai pernyataan karyawan masih kurang memahami pentingnya ketepatan waktu dalam penyelesaian pekerjaannya dan karyawan juga masih kurang memahami dalam proses penyelesaian pekerjaan yang benar. 


\section{Statistik Deskriptif Skor Rata-rata Variabel}

Untuk memberikan gambaran yang lebih jelas mengenai makna hasil perhitungan statistik deskriptif di atas, selanjutnya dibandingkan dengan tabel kriteria penafsiran kondisi variabel penelitian pada masing-masing variabel yang diteliti. Model yang dipakai mengadaptasi model tentang pengontrolan kualitas (J.Supranto, 2001) dapat dilihat pada tabel di bawah ini:

\section{Tabel 8}

Kriteria Penafsiran Kondisi Variabel Penelitian

\begin{tabular}{|c|l|}
\hline Rata-rata Skor & \multicolumn{1}{c|}{ Penafsiran } \\
\hline $4.2-5.0$ & Sangat baik/Sangat tinggi \\
\hline $3.4-4.1$ & Baik/tinggi \\
\hline $2.6-3.3$ & Cukup baik/Cukup tinggi \\
\hline $1.8-2.5$ & Tidak baik/rendah \\
\hline $1.0-1.7$ & Sangat tidak baik/sangat rendah \\
\hline
\end{tabular}

Model pengontrolan kualitas (J.Supranto, 2001)

Berdasarkan hasil perhitungan deskriptif dibandingkan dengan kriteria penafsiran di atas maka diperoleh hasil sebagai berikut

Tabel 9

Kriteria Ketercapaian Skor Tiap Variabel

\begin{tabular}{|c|c|c|}
\hline Variabel & Skor & Kategori \\
\hline Pelatihan & 3,94 & Baik \\
\hline Kinerja & 3,87 & Baik \\
\hline
\end{tabular}

Sumber : Data hasil olahan peneliti, 2016

\section{Analisis Verifikatif.}

1) Koefisien Determinasi

Tabel 10

\section{Koefisien Determinasi}

\begin{tabular}{|l|l|l|l|l|}
\hline Model & $\mathrm{R}$ & R.Square & $\begin{array}{c}\text { Adjusted R } \\
\text { Square }\end{array}$ & $\begin{array}{c}\text { Std Error of } \\
\text { the Estimate }\end{array}$ \\
\hline 1 & $.695_{a}$ & .483 & .476 & .29277 \\
\hline
\end{tabular}

Sumber : Data Hasil pengolahan melalui Sofware SPSS

Hasil perhitungan diatas mengacu tabel $3.2 \mathrm{r}$ sebesar 0,695 artinya tingkat hubungan kuat antara variabel pelatihan (x) dengan kinerja (y) dan koefisien determinasi $\left(r^{2}\right)$ yang dinyatakan dalam persentase mengambarkan besarnya 
kontribusi variabel pelatihan (X), terhadap kinerja karyawan (Y) 48,30\% dan $57,70 \%$ dipengaruhi variabel lainnya yang telah diteliti pada penelitian ini.

\section{2) Koefisien Korelasi.}

Perhitungan koefisien korelasi menggunakan analisis korelasi Pearson Product Moment, dilakukan guna mengetahui seberapa kuat hubungan antara beberapa variabel independen yang diteliti. Perhitungan koefisien korelasi menggunakan program SPSS, dengan hasil seperti yang tertera pada tabel berikut ini

Tabel 11

\section{Koefisien Korelasi Antar Variabel Correlations}

\begin{tabular}{|l|r|r|}
\hline & PELATIHAN & \multicolumn{2}{|c|}{ KINERJA } \\
\hline PELATIHAN Pearson & 1 & $.695^{* *}$ \\
Correlation Sig. (2-tailed) & & .000 \\
N & 70 & 70 \\
\hline KINERJA Pearson Correlation & $.695^{* *}$ & 1 \\
Sig (2-tailed) & .000 & 70 \\
N & 70 & \\
\hline
\end{tabular}

Sumber: Data Hasil pengolahan melalui Sofware SPSS

Berdasarkan tabel tersebut di atas, maka hubungan yang positif antara variabel bebas dengan variabel terikat. Secara keeratan kriteria korelasi adalah sebagai berikut:

\section{3) Regresi Linier Sederhana}

Tabel 12

Nilai Koefisien

\begin{tabular}{|c|c|c|c|c|c|}
\hline \multirow{2}{*}{ Model } & \multicolumn{2}{|c|}{$\begin{array}{c}\text { Unstandardized } \\
\text { Coefficients }\end{array}$} & $\begin{array}{c}\text { Standardized } \\
\text { Coefficients }\end{array}$ & & \\
\cline { 2 - 4 } & $\mathrm{B}$ & Std. Error & Beta & & \\
\hline 1 (Constant) & 1.614 & .285 & & $\mathrm{~T}$ & Sig \\
PELATIHAN & .572 & .072 & .695 & 7.663 & .000 \\
\end{tabular}

a. Dependent Variable : KINERJA

Sumber: Data Hasil pengolahan melalui Sofware SPSS

Berdasarkan tabel diatas maka persamaan regresi linier sederhana adalah sebagai berikut :

$Y=1,614+0,572 X+\epsilon$

Berdasarkan tabel hasil perhitungan analisis regresi linier sederhana :

$\mathrm{a}=1,614$ : nilai constant sebesar 1,614 dengan kata lain bahwa kinerja akan bernilai 1,614 apabila fungsi pelatihan bernilai nol. 
Koefisien regresi $\mathrm{X}: \mathrm{B}=0,572$; secara deskriptif nilai koefisien regresi variabel pelatihan mempunyai pengaruh positif terhadap kinerja, hal ini karena koefisien regresi variabel pelatihan bernilai positif. Artinya apabila terjadi peningkatan skor pelatihan sebesar satu-satuan, pada kondisi skor varibel lainnya sama atau konstan, akan diikuti dengan peningkatan nilai kinerja sebesar 0,572 satuan.

\section{4) Pengujian Hipotesis}

Pengaruh parsial variabel Pelatihan $(\mathrm{X})$ terhadap Kinerja karyawan(Y) perlu dilakukan pengujian statistik, maka mengujinya menggunakan hipotesis statistik sebagai berikut :

$$
\begin{array}{ll}
\mathrm{H}_{0}: \rho_{Y}{ }_{X}=0 & \begin{array}{l}
\text { Tidak terdapat pengaruh pelatihan } \\
\text { terhadap Kinerja karyawan. }
\end{array} \\
\mathrm{H}_{1}: \rho_{Y}{ }_{X} \neq 0 & \begin{array}{l}
\text { Terdapat pengaruh Pelatihan terhadap } \\
\text { Kinerja karyawan. }
\end{array}
\end{array}
$$

Berdasarkan tabel 4.32 dimana uji t hitung didapat probabilitas sebesar $0,00<$ dari 0,05 taraf signifikan. Artinya $\mathrm{H}_{0}$ ditolak $\mathrm{H}_{1}$ diterima jadi terdapat pengaruh pelatihan terhadap kinerja karyawan. Jadi dari penelitian ini sebaiknya Fave hotel Hypersquare selalu terus menerus mengadakan pelatihan agar kinerja karyawan dapat dipertahankan dan ditingkatkan.

\section{SIMPULAN DAN SARAN}

\section{Simpulan}

Berdasarkan rumusan dan hasil pembahasan maka dapat disimpulkan sebagai berikut :

\section{1) Pelatihan}

Secara keseluruhan pelatihan karyawan berada pada kategori baik (khususnya materi yang diberikan telah sesuai dengan kebutuhan pekerjaan. Namun demikian masih terdapat aspek yang lemah, yaitu pada pernyataan mengenai instruktur masih kurang memiliki sikap menyenangkan,

\section{2) Kinerja}

Secara keseluruhan kinerja karyawan pada kreteria baik khususnya karyawan telah memahami kualitas mutlak harus dipenuhi. Namun demikian, masih terdapat aspek yang lemah, yaitu mengenai pernyataan karyawan masih kurang memahami pentingnya ketepatan waktu dalam penyelesaian pekerjaannya dan karyawan juga masih kurang memahami dalam proses penyelesaian pekerjaan yang benar. Hal tersebut penulis simpulkan dari data yang penulis ambil dari bagian personalia yaitu dalam bentuk data-data kinerja dari masing-masing karyawan. 


\section{3) Pengaruh pelatihan terhadap kinerja karyawan}

Hasil perhitungan analisis regresi sederhana dapat diketahui pengaruh pelatihan (X) terhadap kinerja karyawan (Y) di Favehotel Hypersquare dapat dinyatakan positif dan signifikan dimana t hitung sebesar 7.973 lebih besar dari $t$ tabel $=1,98$. Dengan demikian dapat dinyatakan bahwa $\mathrm{H} 0$ ditolak $\mathrm{H} 1$ diterima dengan kata lain terdapat pengaruh signifikan antara variabel pelatihan (X) sebagai variabel independen terhadap variabel kinerja karyawan (Y) sebagai variabel dependent. Hasil penelitian ini membuktikan bahwa hepotesa yang dinyatakan peneliti terbukti, hal ini sesuai dengan teori Menurut Kaswan (2013:55) yang menyatakan bahwa, "Pelatihan yang efektif dapat meningkatkan kinerja, memperbaiki semangat kerja, dan mendongkrak potensi organisasi. Pelatihan yang kurang baik, tidak sesuai, atau tidak memadai bisa menjadi sumber frustasi bagi setiap orang yang terlibat. Untuk memaksimalkan manfaat pelatihan, manager atau pemimpin harus memantau proses pelatihan”. Selain itu pernyataan bahwa pelatihan memiliki hubungan positif dan signifikan terhadap kinerja karyawan sejalan dengan temuan dari Kumara et al (2016).

\section{SARAN}

Saran penulis terhadap pihak manajemen hotel adalah sebagai berikut :

1. Pemberi materi pelatihan disarankan untuk membuat sebuah permainan yang dapat memberikan efek kreatifitas terhadap seluruh peserta hal ini dengan tujuan memberi rasa semangat para peserta dalam melaksanakan program pelatihan.

2. Pelaksanaan program pelatihan harus dilakukan dengan maksimal dan bermanfaat oleh karena itu pihak manager atau pemimpin harus memantau proses pelatihan. Hal tersebut dilakukan agar karyawan dapat memahami proses penyelesaian pekerjaan dengan benar dan dapat menyelesaikan pekerjaan secara benar dan tepat waktu.

\section{DAFTAR PUSTAKA}

Edison, Emron, Yohny Anwar \& Imas Komariyah. (2016). Manajemen Sumber Daya Manusia Strategi dan Perubahan Dalam Rangka Meningkatkan Kinerja Pegawai dan Organisasi. Bandung: Alfabeta.

Hasibuan, Melayu S.P. (2003). Manajemen Sumber Daya Manusia. Majalengka: STIE YPPM.

Kaswan. (2013). Pelatihan Dan Pengembangan untuk Meningkatkan Kinerja SDM. Bandung: Alfabeta.

Komar, R. (2014). Hotel Management. Jakarta: Grasindo

Kumara, I Wayan Sutya Edi, I Wayan Mudiartha Utama. Pengaruh Pelatihan Terhadap Kinerja Karyawan Dengan Mediasi Kepemimpinan Pada Hotel Satriya Cottage Kuta Bali. E-Jurnal Manajemen Unud, (2016) Vol. 5, No.3,2016:1399-1428. ISSN:2302-8912 
Mangkunegara, A. P. (2006). Perencanaan dan Pengembangan Sumber daya Manusia. Bandung: Refika Aditama

Mathis, Robert L. \& Jackson, John H. (2006). Human Resource Management. Jakarta: Salemba Empat.

Pribadi, B. (2014). Desain dan Pengembangan Program Pelatihan Berbasis Kompetensi. Jakarta: Prenada Media Group.

Robbins \& Coulter. (2007).Manajemen. Jakarta: Indeks

Rivai, V. (2005). Manajemen Sumber Daya Manusia untuk Perusahaan, Jakarta: PT Raja grafindo Persada.

Siagian, Sondang.(2007). MPA: Manajemen Sumber Daya Manusia. Jakarta: PT. Bumi Aksara.

Sugiyono,(2016). Metode Penelitian Kuantitatif, Kualitatif, dan R\&D. Bandung: Alfabeta.

Sujarweni, Wiratna. (2014). Metodologi Penelitian. Yogyakarta: PT. Pustaka Baru

Soenarno, Adi.(2003). Kamus Istilah Pariwisata \& Perhotelan. Bandung:

Angkasa

Kartika, Titing, Pramadika, Nurul Rochmah, \& Safari, Apay. Pengaruh Bauran Pemasaran Terhadap Keputusan Berkunjung Wisatawan Di Lawangwangi Creative Space- Dago Giri Bandung. Jurnal Sains Terapan Pariwisata (2016) Vol. 1 No. 1 